\title{
Analysis and Forecasting of the Primary Energy Consumption in Poland Using Deep Learning
}

\author{
Anna MANOWSKA ${ }^{1)}$
}

\footnotetext{
1) Ph.D., Eng Silesian University of Technology, Faculty of Mining, Safety Engineering and Industrial Automation; email: anna.manowska@polsl.pl
}

http://doi.org/10.29227/IM-2020-01-77

Submission date: 02-12-2019 | Review date: 06-01-2020

Abstract
Consumption of fossil energy resources were increased dramatically, due to the economic and population growth. In turn, the con-
sumption of fossil resources causes depletion of resources and contributes to environmental pollution. The European Union's "climate
neutrality" initiative requires effective energy management from the member states. By this is meant a resource-efficient and com-
petitive economy in which there is no greenhouse gas emission and where economic growth is decoupled from resource consumption.
The article analyzes the level of primary energy consumption in Poland. It was examined whether a 23\% drop in energy consumption
could be achieved in 2030 compared to the base year and according with energy efficiency assumptions. A methodology for forecasting
primary energy consumption based on deep neural networks, in particular on Long Short Term Memory (LSTM) algorithms was also
presented.

Keywords: primary energy consumption, deep learning methods, long short-term memory, deep neural network

\section{Introduction}

The large scale consumption of energy resources not only reflects the rapid growth of economic and population, but also contributes to the environmental pollution $[1,2]$. Effective implementation of pollution prevention and energy efficiency initiatives are often supported by an effective energy management, which must identify and forecast energy consumption to correctly identify the relationship between energy consumption, environmental and climate degradation, and optimize existing systems and resources towards sustainable development. Therefore, it is obvious that energy consumption forecasting is the fundamental of energy sector's management. The document "The European Green Deal" [3] approved by the member states of the European Union sets out the objectives that Europe must achieve by 2050 regarding climate neutrality $[4,5,6,7]$. It is a new strategy for transforming the EU into a fair and prosperous society, with a modern, resource-efficient and competitive economy that has no net greenhouse gas emissions and where economic growth is decoupled from resource use [3]. The European Commission in the Clean Planet for All strategy, a European long-term strategic vision for a prosperous, modern, competitive and climate neutral economy (COM (2018) 773) [8] has identified how it wants to achieve climate neutrality. The priority is to further reduce the emission of the energy system and increase the share of renewable energy sources while simultaneously withdrawing from coal at a rapid pace. By 2030, the EU puts an emphasis on developing energy efficiency. These are requirements for buildings, household appliances, electronics and lighting, but also for the transport sector. The strategy assumes the popularization of electric and hybrid vehicles so that the demand for crude oil is expected to remain at the level of 2019. In addition, the national energy system is to be strongly modernized, increasing the efficiency of energy production (PEP2040) [9]. All these activities are to reduce primary energy demand. The goal for Poland is to achieve savings of $23 \%$ of primary energy and $21.5 \%$ of final energy in 2030 relative to the base -2007 .

Poland consumes approximately 4,400 PJ of primary energy, with the majority being hard coal and crude oil, next natural gas, lignite and renewable sources [10]. Figure 1 shows the current and future primary energy consumption in Poland according to various scenarios $[11,12]$.

In the ARE scenario and the reference GreenPeace, demand for primary energy will increase until 2030, with additional demand being met by renewable energy, nuclear energy and gas. This will lead to diversification of the mix and reduction of the relative role of coal in it. The GreenPeace alternative scenario assumes a decrease in primary energy demand. In comparison to the reference scenario, primary energy consumption in 2030 will be lower by $27 \%$. Despite this, energy needs will be fully balanced - there is no problem of energy shortage on the market or lowering the standard of living of the inhabitants or productivity of the economy. The most important effect of implementing the alternative scenario is reducing the economy's dependence on conventional fuels, including oil imports. The place of fossil fuels is taken by renewable energy sources, with significant shares of wind, biomass and solar energy. A significant increase in the share of renewable energy is possible by to the improvement of equipment efficiency and reduction of technology costs. This mainly applies to solar farms and wind energy.

The purpose of this article is to develop a predictive model of primary energy consumption using deep learning methods, which will answer the question, will Poland manage to achieve the assumed level of energy efficiency? The measure of this level will be the analysis of the trend in the development of primary energy consumption until 2040 and the determination of the level of demand in 2030. It should be noted that the demand for primary energy is a derivative of the demand 


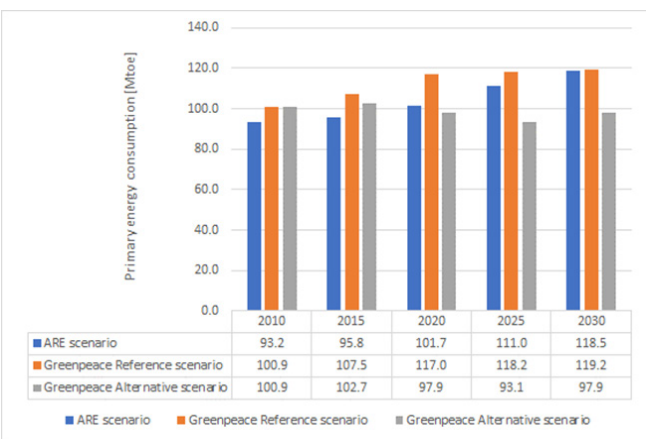

Fig. 1. Real and forecasted primary energy consumption. Source: own elaboration

Rys. 1. Rzeczywiste i prognozowane wartości zużycia energii pierwotnej. Źródło: opracowanie własne

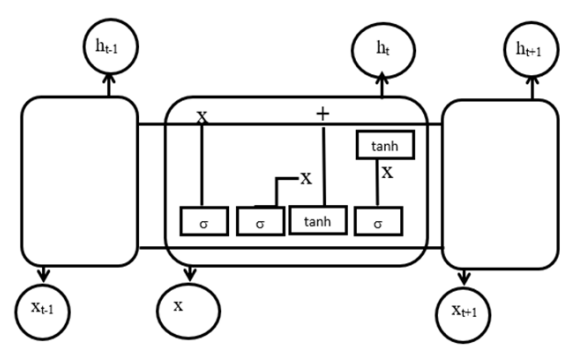

Fig. 2. Structure of the long short-term memory. Source: own elaboration Rys. 2. Struktura komórki sieci neuronowej LSTM. Źródło: opracowanie własne

for final energy. Thus, all changes in the final energy structure and reduction of energy transmission losses are visible in future primary energy demand. Therefore, it was decided to build a model based on the history of the phenomenon and taking into account the population and GDP.

\section{Methodology and Data}

There are no methods in the world and domestic literature for forecasting of the total amount the consumption of primary energy. There are only studies on forecasting the consumption of each energy resources . In these studies, conventional models and models based on artificial intelligence were used to forecast consumption [13]. Conventional models are divided into time series models (mainly ARMA, ARIMA, SARIMA) and regression models $[14,15,16]$. Models based on artificial intelligence are grouped into artificial neural network models and machine learning models [17, 18, 19]. Review results show that conventional models are preferred for short-term energy consumption forecasts. Among them, non-linear regression models can describe the relationship between consumption data and influencing factors. Artificial intelligence based models have the ability to adapt in all areas and forecasting horizons [13].

In artificial intelligence literature, deep learning models have been identified among machine learning methods [20]. These methods are distinguished from typical neural networks by a greater number of neurons in the layer, by more complex methods of connecting layers in the network and by automatic extraction of functions. The algorithms most commonly used to predict time series during deep learning are recurrent neural network (RNN), long short-term memory (LSTM) and gated recurrent unit (GRU). LSTM networks have three very important aspects that distinguish them from other recursive networks. When designing the network, it is necessary to decide which input data will be entered into the neuron, whether to remember the results of the calculations made in the previous step and when the input data will be forwarded to the next time stamp, as shown in Figure 2.

The functions shown in Figure 2 are defined as follows [21]:

$$
\begin{gathered}
f_{t}=\sigma\left(w_{f} \times\left[h_{t-1}, x_{t}\right]+b_{f}\right) \\
i_{t}=\sigma\left(w_{i} \times\left[h_{t-1}, x_{t}\right]+b_{i}\right) \\
\widetilde{C_{t}}=\tanh \left(w_{c} \times\left[h_{t-1}, x_{t}\right]+b_{c}\right) \\
C_{t}=f_{t} \times C_{t-1}+i_{t} \times \widetilde{C}_{t} \\
o_{t}=\sigma\left(w_{o} \times\left[h_{t-1}, x_{t}\right]+b_{o}\right) \\
h_{t}=o_{t} \times \tanh \left(C_{t}\right)
\end{gathered}
$$

where: $x t-1$ and $x t$ are the previous and current input values, respectively; ht-1and ht are the 193 previous and current hidden gates, respectively; $\mathrm{Ct}-1$ andCt are the previous and current cell states, 194 respectively; wf, wi, wc, and wo are the weight values connecting the input to each gate; bf, bi, bc, 195 and bo are the bias values for each gate's calculation; $\sigma$ is a sigmoid function; and tanh is a 196 hyperbolic tangent function.

In addition, these networks cope well with long-term relationships. This article presents the LSTM networks to predict primary energy consumption. The input data to the model concern primary energy consumption, population and GDP $[22,23]$, as shown in Figure 3.

The population between 1995 and 2018 has decreased from 38.60 to 37.80 million. The average annual decrease is at the level of $3 \%$. Gross domestic product has increased over the years 1995-2018 very rapidly, by about $400 \%$, while primary energy consumption has increased very moderately from 95.3 Mtoe in 1995 to 105, 2 Mtoe in 2018.

In this paper is adopted two widely used performance metrics: mean absolute error (MAE), root mean square er- 


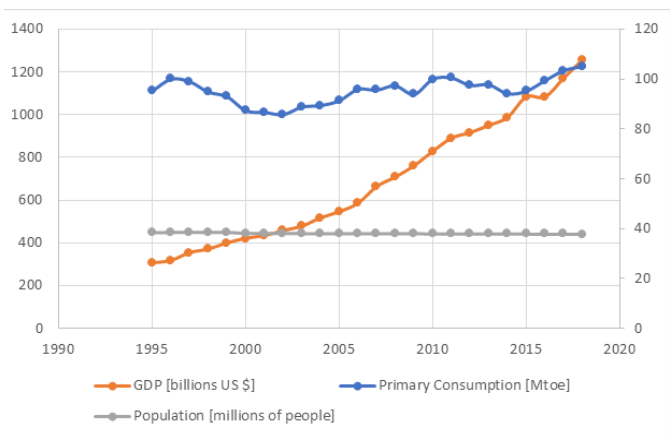

Fig. 3. Input data to the model. Source: own elaboration

Rys. 3. Dane wejściowe do modelu. Źródło: opracowanie własne

\begin{tabular}{|c|c|c|}
\hline Layer (type) & Output Shape & Param \# \\
\hline 1stm_39 (LSTM) & (None, 8,4 ) & 96 \\
\hline 1stm_40 (LSTM) & (None, 4) & 144 \\
\hline dense_21 (Dense) & (None, 1) & 5 \\
\hline
\end{tabular}

Total params: 245

Trainable params: 245

Non-trainable params: $\theta$

Fig. 4. The multivariate model for forecasting consumption primary energy (model no. 1). Source: own elaboration Rys. 4. Model wielowymiarowy do prognozowania zużycia energii pierwotnej (model nr 1). Źródło: opracowanie własne

\begin{tabular}{|c|c|c|}
\hline Layer (type) & Output Shape & Param \# \\
\hline $\begin{array}{l}== \pm==\equiv=\equiv=\equiv== \\
1 \mathrm{stm} 31 \text { (LSTM) }\end{array}$ & 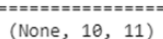 & $\begin{array}{l}= \pm= \pm= \pm=3 \\
572\end{array}$ \\
\hline 1stm_32 (LSTM) & (None, 11) & 1012 \\
\hline dropout_8 (Dropout) & (None, 11) & $\theta$ \\
\hline dense_18 (Dense) & (None, 1) & 12 \\
\hline
\end{tabular}

Fig. 5. The multivariate model for forecasting consumption primary energy (model no. 2). Source: own elaboration Rys. 5. Model wielowymiarowy do prognozowania zużycia energii pierwotnej (model nr 2). Źródło: opracowanie własne

ror (RMSE) to assess the prediction accuracy of the proposed methods [24]:

$$
\begin{aligned}
& M A E=\frac{1}{n} \cdot \sum_{i=1}^{n}\left(\left|y_{i}-\hat{y}_{i}\right|\right) \\
& R M A E=\sqrt{\frac{1}{n} \cdot \sum_{i=1}^{n}\left(y_{i}-\hat{y}_{i}\right)^{2}}
\end{aligned}
$$

where: $y_{i}$ identifies the actual value for sample $i ; \hat{y}_{i}$ identifies the predicted value for sample $\mathrm{i} ; \mathrm{n}$ is the testing data

\section{Results}

The first model was proposed as shown in figure 4 and it is designed from the input - LSTM, the hidden - dropout to the output - dense layer. The input layer this is historical data connected with the consumption primary energy. The output layer this is prediction.

The second model was proposed as shown in figure 5 and it is designed from the input layers - LSTM, hiden - dropout to the output - dense layer. The input layer this is historical data connected with the consumption primary energy, GDP and population. The output layer this is prediction.
The data was divided the learning data into $70 \%$ and training data into $30 \%$. Table 1 summarizes the simulation parameters used in this study.

Figure no. 6 and table no. 2 shows comparison the models for the long-term consumption primary energy. Lower values of MAE, RMSE denote a higher model accuracy.

The results have obtained from model 1 and model 2 are similar. The structure of model no. 2 includes explanatory variables that also need to be forecasted. This significantly affects the residuals of the model.

In the first model based only on the history of the phenomenon, the errors are $1 \%$. It means that the model has adapted to the real flow in a high level. The advantage of this model is that the forecast is generated only on the historical of the primary energy consumption. In the second model, the errors are $2 \%$. Increasing of the errors is due to forecasting of explanatory variables, however, fitting of the model is also high. Explaining variables have been predicted by regression models. Figure 7 shows the forecast of primary energy consumption.

Poland's primary energy consumption has predicted by two models, and the results are shown in figure 7 . In the 
Tab. 1. Simulation parameters. Source: own elaboration

Tab. 1. Parametry symulacji. Źródło: opracowanie własne

\begin{tabular}{|l|l|l|}
\hline & Model no. 1 & Model no. 2 \\
\hline Number of layers & 3 & 4 \\
\hline Number of neurons & 15 & 24 \\
\hline Number of epochs & 25 & 30 \\
\hline Learning rate & 0,05 & 0,05 \\
\hline Loss function & MSE & MSE \\
\hline Optimizer & ADAM & ADAM \\
\hline Weight initializer & 1 & 1 \\
\hline Activation function & ReLU & ReLU \\
\hline
\end{tabular}

Tab. 1. Simulation parameters. Source: own elaboration

Tab. 1. Parametry symulacji. Źródło: opracowanie własne

\begin{tabular}{|l|c|c|}
\hline & Model no. 1 & Model no. 2 \\
\hline MAE & 0,53 & 1,56 \\
\hline RMAE & $1 \%$ & $2 \%$ \\
\hline
\end{tabular}

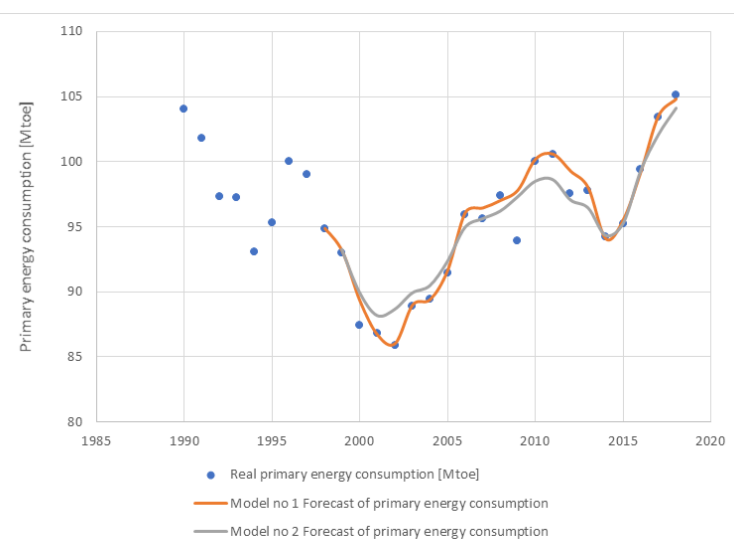

Fig. 6. Comparison of the real and forecast of primary energy consumption. Source: own elaboration Rys. 6. Porównanie rzeczywistego i prognozowanego zużycia energii pierwotnej. Źródło: opracowanie własne

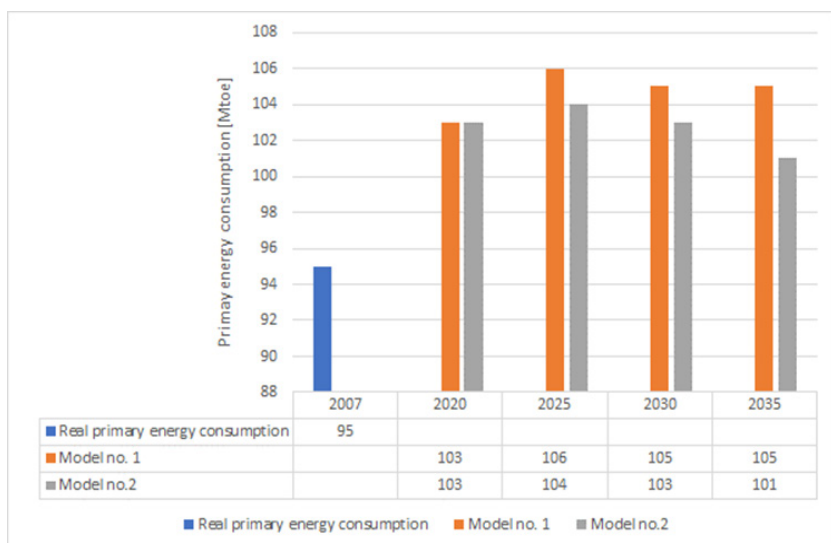

Fig. 7. The forecast of primary energy consumption. Source: own elaboration Rys. 7. Prognoza zużycia energii pierwotnej. Źródło: opracowanie własne

model no.1, based only on the history of the phenomenon, energy consumption is higher by about $2 \%$ compared to the model no 2. This is the result of relation between Poland's energy consumption and economic growth and population. This data has been added in the model no 2, as a explanatory variables. The model has presented slower growth of primary energy consumption, and after year 2025 the decreasing this consumption. Reducing energy consumption is a priority in the EU. Actions to improve energy efficiency are not only as a methods of ensuring sustainable energy supplies, reducing greenhouse gas emissions, increasing security of supply and reducing expenditure on energy imports, but also promotion of EU competitiveness. The national target for improving energy efficiency is $23 \%$ in the 2030 and it is calculated in relation to primary energy from 2007. In absolute terms, it amounts to 91.3 Mtoe in 2030. In the developed models, the value of primary energy is 105 Mtoe and 103 Mtoe and is higher than the assumptions by $12 \%$ and $11 \%$. 


\section{Discussion and Conclusions}

The policy of the European Union is focused on environmental protection. An expression of these trends is newly adopted "European Green Deal", which assume climate neutrality until 2050. To achieve this goal, European Union members have already taken various initiatives. One of these initiatives is reduction of primary energy consumption and increase energy efficiency. The article analyses whether Poland will manage to achieve a $23 \%$ reduction of primary energy consumption compared to 2007. This reduction would be the result of an increase in energy efficiency. To analyse the problem, two models have built for forecasting primary energy consumption based on artificial neural networks with the LSTM algorithm. The first model was built only on the history of the phenomenon, while in the second one added explanatory variables: population and GDP. A review of the literature in chapter 2 and model fit metrics in chapter 3 confirm the effectiveness of neural networks to predict time series. The forecasts presented in the article show a decrease in primary energy consumption by about $1.5 \%$ after 2025 . However, this decrease is insufficient to achieve a reduction of primary energy consumption by $23 \%$ compared to the base year in 2030

\section{Literatura - References}

1. Suganthi, L.; Samuel, A.A. Energy models for demand forecasting—a review Renew. Sustainable Energy Review., 2012, 1223-1240.

2. Fuinhas, J.A.; Marques, A.C. Energy consumption and economic growth nexus in Portugal, Italy, Greece, Spain and Turkey: an ARDL bounds test approach (1965-2009). Energy Economics., 2012, 34 (2), 511-517.

3. European Commission: The European Green Deal.

4. Manowska, A.; Nowrot, A. The importance of heat emission caused by global energy production in terms of climate impact. Energies 2019, 12, 16, 1-12. https://doi.org/10.3390/en12163069.

5. Bluszcz, A. The emissivity and energy intensity in EU countries - consequences for the Polish economy. Conference proceedings Energy and clean technologies. Recycling, air pollution and climate change. STEF92 2018, 18, 14.2, 631-638 Sofia. https://doi.org// 10.5593/sgem2018/4.2/S19.081.

6. Kijewska, A.; Bluszcz, A. Analysis of greenhouse gas emissions in the European Union with the use of agglomeration algorithm. Journal of Sustainable Mining, 2016, 15, 4 133-142 DOI 10.1016/j.jsm.2017.02.001.

7. Sobczyk, W.; Pelc, P.; Kowal, B.; Ranosz, R. Ecological and economical aspects of solar energy use E3S Web of Conferences [Dokument elektroniczny]. - Czasopismo elektroniczne ; ISSN 2267-1242, 2017, 14, 01011, 1-8.

8. European Commission: A Clean Planet for all A European long-term strategic vision for a prosperous, modern, competitive and climate neutral economy, COM (2018) 773, 2018.

9. Ministry of State Assets, Poland's energy policy until 2040. PEP2040, 2018.

10. GUS, Energy 2018, 2019.

11. ARE, Prognoza zapotrzebowania na paliwa i energię do 2030 roku, załącznik do Polityki Energetycznej Polski do 2030 roku. ARE (2011), Aktualizacja Prognozy zapotrzebowania na paliwa i energię do roku 2030, Warszawa. Bank Światowy (2011), Transition to a Low-Emissions Economy in Poland, 2009.

12. Greenpeace Polska, [R] ewolucja energetyczna dla Polski. Scenariusz zaopatrzenia Polski w czyste nośniki energii w perspektywie długookresowej, Warszawa, 2008.

13. Wei, N.; Changjun, L.; Xiaolong, P.; Fanhua, Z.; Xinqian, L. Conventional models and artificial intelligence-based models for energy consumption forecasting: a review. Journal of Petroleum Science and Engineering 2019, 181, 5650-5663.

14. Zhao, G.; Guo, S.; Jing, S.; Wang, Y. An investigation of coal demand in China based on the variable weight combination forecasting model. Journal of Resources and Ecology 2011, 2 (2), 126-131.

15. Shao, Z.; Gao, F.; Yang, S.-L.; Yu, B.-g. A new semiparametric and EEMD based framework for mid-term electricity demand forecasting in China: hidden characteristic extraction and probability density prediction. Sustainable Energy Review 2015, 52, 876-889.

16. Ervural, B.C.; Beyca, O.F.; Zaim, S. Model estimation of ARMA using genetic algorithms: a case study of forecasting natural gas consumption. Procedia - Social and Behavioral Sciences 2016, 235, 537-545. 
17. Ding, S. A novel self-adapting intelligent grey model for forecasting China's natural-gas demand. Energy 2018, 162, 393-407.

18. Jurado, S.; Nebot, À.; Mugica, F.; Avellana, N. Hybrid methodologies for electricity load forecasting: entropy-based feature selection with machine learning and soft computing techniques. Energy 2015, 86, pp. 276-291.

19. Shayeghi, H.; Ghasemi, A.; Moradzadeh, M.; Nooshyar, M. Simultaneous day-ahead forecasting of electricity price and load in smart grids. Energy Conversion and Management 2015, 95, 371-384.

20. Li, J. The 10 Deep Learning Methods AI Practitioners Need to Apply, 2017, [access date 2020-05-12]

21. Hochreiter, S.; Schmidhuber, J. Long short-term memory, Neural Computation 1997, 9 (8): 1735-1780.

22. www.macrotrends.net, [access date 2020-05-02]

23. BP: bp-stats-review-2019-all-data, [access date 2020-05-02]

24. Zielaś, A.; Pawełek, B.; Wanat, S. Prognozowanie ekonomiczne, teoria, przykłady, zadana. Wydawnictwo Naukowe PWN, 2003.

\section{Analiza i prognozowanie zużycia energii pierwotnej w Polsce z wykorzystaniem technik głębo- kiego uczenia}

Zużycie kopalnych surowców energetycznych wzrasta, a wzrost ten jest skorelowany ze wzrostem ludności i rozwojem gospodarczym. $Z$ kolei zużycie kopalnych surowców energetycznych powoduje wyczerpywanie się zasobów i przyczynia się do zanieczyszczenia środowiska. Inicjatywa Unii Europejskiej "neutralność klimatyczna" wymaga od państw członkowskich efektywnego zarządzania energią. Przez co rozumie się zasobooszczędną i konkurencyjna gospodarką, w której nie ma emisji netto gazów cieplarnianych i gdzie wzrost gospodarczy jest oddzielony od zużycia zasobów. W artykule przeanalizowano poziom zużycia energii pierwotnej w Polsce. Zbadano, czy w roku 2030 uda się osiągnąć $23 \%$ spadek konsumpcji energii $w$ odniesieniu do roku bazowego, zgodnie z przyjętymi założeniami o efektywności energetycznej. Przedstawiono również metodologię prognozowania zużycia energii pierwotnej oparta na głębokich sieciach neuronowych, w szczególności na algorytmach Long Short Term Memory (LSTM).

Słowa kluczowe: konsumpcja energii pierwotnej, metody głębokiego uczenia, sztuczne sieci neuronowe, LSTM 